WellBeing International

WBI Studies Repository

4-2014

\title{
Abolition Then and Now: Tactical Comparisons Between the Human Rights Movement and the Modern Nonhuman Animal Rights Movement in the United States
}

Corey Lee Wrenn

Colorado State University, corey.wrenn@gmail.com

Follow this and additional works at: https://www.wellbeingintlstudiesrepository.org/anirmov

Part of the Animal Studies Commons, Civic and Community Engagement Commons, and the Politics and Social Change Commons

\section{Recommended Citation}

Wrenn, C. L. (2014). Abolition then and now: Tactical comparisons between the human rights movement and the modern nonhuman animal rights movement in the united states. Journal of agricultural and environmental ethics, 27(2), 177-200.

This material is brought to you for free and open access by WellBeing International. It has been accepted for inclusion by an authorized administrator of the WBI Studies Repository. For more information, please contact wbisr-info@wellbeingintl.org.

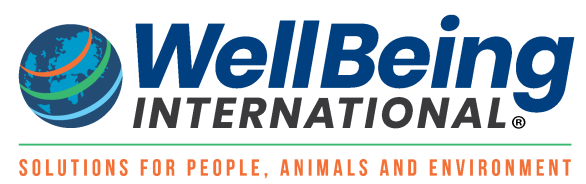




\title{
Abolition Then and Now: Tactical Comparisons Between the Human Rights Movement and the Modern Nonhuman Animal Rights Movement in the United States
}

\author{
Corey Lee Wrenn \\ Colorado State University
}

\begin{abstract}
KEYWORDS
abolition, animal rights, human rights, slavery, social movements
\end{abstract}

\begin{abstract}
This article discusses critical comparisons between the human and nonhuman abolitionist movements in the United States. The modern nonhuman abolitionist movement is, in some ways, an extension of the anti-slavery movement of the eighteenth and nineteenth centuries and the ongoing human Civil Rights movement. As such, there is considerable overlap between the two movements, specifically in the need to simultaneously address property status and oppressive ideology. Despite intentional appropriation of terminology and numerous similarities in mobilization efforts, there has been disappointingly little academic discussion on this relationship. There are significant contentions regarding mobilization and goal attainment in the human abolitionist movement that speak to modern collective action on behalf of other animals. This article will explore the human abolitionist movement and discuss possible applications of movement organization, tactical repertoires, and goal attainment to the current nonhuman animal rights movement. Specifically, the utility of violence and legislative activism in the antislavery movement are discussed as potentially problematic approaches to abolishing nonhuman animal exploitation. Alternatively, the nonhuman animal rights focus on consumer resistance and nonviolence represent an important divergence in abolitionist mobilization.
\end{abstract}

\section{Introduction}

The nonhuman animal rights movement, formed for the general goal of advancing the interests of other animals, has been functionally existent since the early nineteenth century (Beers 2006). Originally concerned with reforming treatment of urban work horses and stray dogs, by the mid twentieth century the movement had been significantly influenced by Civil Rights mobilization efforts and had begun to push for more radical goals that included animals used for food, entertainment, experimentation, and companionship. By the 1970s, many activists were calling for a complete abolition to nonhuman animal exploitation. Similar to many movements of the era, the nonhuman animal rights movement experienced a wave of professionalization: groups grew in size to increase their political influence and mobilizing strength, and, in order to stabilize and secure resources, began to moderate their tactics and goals (Piven 
and Cloward 1977). By the 1990s, most major nonhuman animal rights organizations seemed to resemble one another in structure and repertoire; few were effecting any real change (Francione 1996). Welfare reform has become standard protocol and organizations that had initially formed for the advancement of other animals now find themselves pushing for regulations that, according to their own economic reports (PETA 2007), promise to improve efficiency and productivity for exploitative industries (Francione and Garner 2010). This is a considerable trade-off and has troubled many advocates.

In many social movement environments that have experienced counterproductive professionalization and moderation, radical factions have emerged (Zald and Ash 1966) and this has certainly been the case for nonhuman animal rights. With his entrance to the online activist community in the mid 2000's, Gary Francione spearheaded the formation of what he called the "abolitionist approach to animal rights." Sharply critical of the shortcomings of a compromised movement, Francione $(1996,2010)$ renounced the effectiveness of professionalized groups that had become bound to organizational maintenance and were largely hesitant to present any meaningful challenge to exploitative industries. Such organizations, he argues, fail to address the property status of nonhuman animals, and, in fact, reinforce commodification through regulationist measures and a reluctance to promote veganism. Francione's abolitionist approach, then, calls for a recognition of the personhood of other animals and the equal consideration of their interests based on their self-awareness and capacity to suffer.

Francione's abolitionist approach harkens quite obviously to the antislavery rhetoric of human rights advocates in antebellum America, but the nonhuman animal rights movement has, from its inception, drawn quite heavily on the human abolitionist movement (Beers 2006). Nonhuman activists of the nineteenth century drew parallels between similar oppressive systems facing human and nonhuman slaves. Writing in 1898, nonhuman activist Henry Salt summarizes the basis for this appropriation:

The present condition of the more highly organized domestic animals is in many ways very analogous to that of the negro slaves of a 100 years ago: look back, and you will find in their case precisely the same exclusion from the common pale of humanity; the same hypocritical fallacies, to justice that exclusion; and, as a consequence, the same deliberate stubborn denial of their social "rights." (1980: 21).

Antislavery mobilization inspired and validated human activists in applying natural rights to other species (Beers 2006). The subhuman label and property status given to slaves justified their unequal treatment, and this had important implications for nonhumans as well. Early activists adopted many human abolitionist tactics, namely moral suasion. Salt, in particular, favored education as an "indispensable condition of humanitarian progress" (1980: 119).

Nearly a century later, Billy Ray Boyd published a brief essay The New Abolitionists: Animal Rights and Human Liberation (1987) that reintroduces the commonalities between the human and nonhuman abolitionist movements to a modern audience. Boyd rightly points out the necessity for recognizing intersectionality between the various manifestations of inequality. He urges activists to challenge the domination of others and to extend their "circle of concern" to all species. Spiegel's 1988 The Dreaded Comparison: Human and Animal Slavery elaborates the connections between human and nonhuman exploitation, powerlessness, and ideological barriers and argues that the experiences of both are strikingly similar. Francione, of course, credits his "Abolitionist Approach" to nonhuman animal rights to the antislavery movement in regards to the property status of nonhumans:

The rights position as I propose it maintains that [...] we cannot make meaningful distinctions between the quality of sentient experiences between humans and nonhumans that would justify imposing any pain and suffering on nonhumans incidental to our use of them as our resources, any more than we can make 
such distinctions between or among humans for the purpose of justifying slavery or otherwise treating humans exclusively as resources. (Francione and Garner 2010: 24-25).

Francione furthers that there is an important parallel between the two movements in that the "[...] fundamental interests of sentient beings are commodified and treated as tradable depending on economic consequences" (Francione and Garner 2010: 229). DeCoux (2009) also draws on the many tactical similarities between the two movements in emphasizing the importance of graphic imagery, narratives, and other depictions of suffering in motivating participation. Nibert (2002), too, elaborates on the complex relationship between human and nonhuman oppression, arguing that human and nonhuman inequality have developed in tandem and both experiences ultimately aggravate and reinforce one another.

Beyond these conceptual comparisons, however, the literature has been largely silent on the historical influence of the human movement and the important similarities that exist. This is unfortunate because direct appropriation has been cited as an important vehicle of mobilization (McAdam et al. 2001). While excluded from traditional social movement models, appropriation is an important mechanism for oppressed or resource-poor groups. Marginalized groups might quickly gain a sense of identity and legitimacy in drawing on other movements. This appropriation also represents the interactive nature of social movements, which exist in a dynamic relation with one another, a reality that is also often ignored in traditional models.

The antislavery movement, with its goal in dismantling the property status of persons, and, later, the oppressive ideologies that had supported it, was a ripe source for appropriation. While the abolition of slavery in the United States was largely a reaction to economic tensions of the era (Williams 1994) and was ultimately achieved with the political upheaval of the Civil War, abolitionist activity certainly impacted national politics and helped create an antislavery culture (Ashworth 1995). American abolitionism built upon the earlier campaigning undertaken by Quakers, gradualists, and colonizationists and was heavily inspired by British movement activities (Ferrell 2006). Just as varied as its inspirations were its tactics and ideologies. Typical of other social movements that quite naturally dispute over how to frame the problem, the solution, and the motivations for participation (Benford and Snow 2000), the abolitionist movement was heavily factionalized and divided over the use of violence, moral suasion, and legal and religious institutions.

Because many of these divisions have manifested in nonhuman animal advocacy as well, an exploration into the mobilization efforts of human abolitionists in the eighteenth, nineteenth, and twentieth centuries could prove an important untapped resource for modern nonhuman abolitionists. In particular, I examine the tactical repertoires of human abolitionists in an effort to inform the nonhuman movement in regards to the use of violence, direct action, legal mobilization, consumer-based resistance, and moral suasion. In this, I will also elaborate on important differences between the two movements that serve to complicate goal attainment. For example, language, domestication, and other important species-related barriers do exist that should be recognized.

Given the many similarities of experience between the two groups, the implementation of particular tactics in human abolitionism and their relationship to movement success could prove a fruitful resource for the nonhuman movement. In the United States, the destruction of slavery was expedited by political and economic realities, but the collective action undertaken by African Americans and other abolitionists most certainly played an important role in influencing this change. While political and economic environments are recognized as important, it is the intention of this paper to address abolitionist mobilization that is concerned with ending slavery and discrimination as an ethical necessity. This focus on mobilized 
morality ignores any potential rights-neutral social gains associated with abolition such as the prevention of violent rebellions, the stabilization of the work force, or the facilitating of industrialization.

The human abolitionist movement sought not only to end the property status of humans, but lives on in its attempt to dismantle the prevailing discriminatory ideology that continues to reinforce inequality beyond enslavement. This point in particular could prove relevant to the nonhuman movement, particularly in the criticisms that have surfaced regarding Francione's hyperfocus on nonhumans as property. Francione and Garner (2010) and DeCoux (2009), for instance, have challenged that too much emphasis has been placed on abolishing nonhuman property status at the expense of supporting efforts that could potentially address nonhuman suffering. Yet, drawing on the human movement, I argue that an attack on the property status of nonhumans must coincide with an attack on discriminatory ideology. Following the Francionian approach to nonhuman animal rights, an emphasis on suffering would be unproductive if it does not seriously challenge the political and ideological structures that maintain it. Indeed, Francione has countered that an overreliance on suffering might detract from the critical need to challenge speciesism and enslavement, thus complicating nonhuman liberation (Francione and Garner 2010). As such, Francione suggests that abolitionists concentrate their efforts on the promotion of veganism, which rejects the use and exploitation of nonhumans, but also works to dismantle speciesism. Implicit with this approach is a move away from suffering as the prominent concern, as this is thought to encourage insignificant reforms that complicate and hinder abolition (Francione 1996).

\section{Connections to the Nonhuman Abolitionist Movement}

As we have seen, the nonhuman abolitionist movement has appropriated the human experience as a means of drawing attention to the similar manifestations of oppression in both instances. Both minority groups, it is argued, have experienced slavery, ignored personhood, and endured extreme discrimination. Yet, the nonhuman appropriation of the human abolitionist experience has not gone without critique. Kim (2011) has noted that, while human-nonhuman abolitionist analogies hold weight, they could prove problematic in creating movement alliances as they often lack sensitivity and can alienate many demographics. In an interview with The Daily Show, activist Elaine Brown (2012) takes issue with PETA's lawsuit that compares orcas to African slaves in an attempt to have them protected as persons under the 13th Amendment. Brown calls the campaign "beyond insulting" and a "cruel and racist joke." "Animal cruelty," she says, "does not rise to slavery. [...] Part of the slave condition was that blacks were not really human beings [...]." Because African Americans were often compared to nonhumans as a means to dehumanize and otherize to justify oppression, tension often results in putting African Americans and nonhumans on the same level of concern. PETA's insensitive campaigns that compared nonhuman animal exploitation to the Holocaust have elicited similar offense (Kim 2011). Spiegel counters this reaction in arguing that comparing human and nonhuman experiences is not to degrade the former but to elevate the latter: "Comparing the suffering of animals to that of blacks (or any other oppressed group) is offensive only to the speciesist: one who has embraced the false notions of what animals are like" (1996: 30). Writing on the similarities between the Jewish and nonhuman experience, activist Karen Davis (2005) suggests this offense arises primarily from our threatened superior status as humans.

Regardless, the ideological dichotomy between human and nonhuman has yet to be significantly challenged. Thus, comparing the two groups can quickly become insulting. Nonhuman abolitionists, therefore, should aim to practice sensitivity in regards to the historical comparisons of human groups to nonhumans. Overcoming this offense is no easy task, but it might perhaps be tempered in recognizing the human tendency towards homophyly, or an ingroup bias for humans that necessarily otherizes and excludes nonhumans. Nonhuman animal activists, however, hope to extend the boundaries of moral concern to include other animals who are sentient, self-aware, and have the potential to suffer. Just as human rights activists draw on the shared humanness of slaves and oppressed humans to argue for their 
inclusion in the larger human rights arena, nonhuman animal rights activists draw on the shared sentience of enslaved and oppressed nonhuman animals.

There are other considerations that could become problematic in determining the appropriateness of comparing the two groups. Importantly, human abolitionist activism extends beyond the property status of humans. For instance, after the failed efforts of the American Reconstruction era, DuBois focused on deconstructing racism and segregation (Lewis 1995). More recently, Davis (2005) has challenged continued loss of power and personhood for African Americans as perpetuated by the American prison system. The concern here is that oppression for African Americans reaches beyond property status and infiltrates many social institutions. In addition to Davis's focus on the prison system, African Americans are disadvantaged in occupational, educational, and housing opportunities. Human abolitionist work, then, has moved beyond the physical enslavement of people of color and has begun to challenge other manifestations of prejudice. This is in contrast to the nonhuman abolitionist movement, which is primarily concerned with eradicating use. While speciesism is often included in claims-making, it remains that the majority of nonhuman mobilization is focused on property status. There has been little speculation into how society might continue to oppress nonhumans after liberation is achieved and how the movement might prepare for that challenge.

What's more, there are distinct objective qualities between the two minority groups that challenge comparisons. Language barriers and a history of domestication, in particular, have provided special challenges for the nonhuman movement. Because nonhumans cannot speak on their own behalf, advocates are not able to draw on personal narratives that have proven to be powerful motivational tools for other social movements, particularly the human abolitionist cause. Domestication, too, acts as a serious barrier. For instance, centuries of selective breeding has created psychological docility and physical dependency in many nonhuman species. This prevents the vast majority of nonhumans from engaging in their own resistance. However, it should be noted that similar processes were at work against human slaves to destroy their ability to speak and act on their own behalf. Laws were passed in the American South, for example, which banned African Americans from receiving an education (Cornelius 1991) and mobs routinely attacked sites of African American education in the North (Moss 2009). Education, of course, was an important means for allowing African Americans to give voice to their condition and to overcome acquiescence. The judicial system often failed people of color as well; and African Americans were prohibited from testifying against whites in court in many regions (Campbell 2007). Social-economic and cultural realities of a slave-based system also meant that imagining a life beyond the plantation was a difficult task for African Americans who were often a product of many generations of slave existence. Powerful ideological constraints (that were often internalized by the slaves themselves), repressive laws, and limited opportunities for both runaways and free blacks meant that slave resistance was unlikely.

Thus, while many important distinctions between the groups remain, there are a number of oppression mechanisms that do operate similarly in both instances. So, too, do the movement dynamics, claimsmaking, and tactics hold similar. Therefore, with these similarities in mind and with a recognition that both experiences hold their own individual worth and uniqueness that should be treated with sensitivity, this paper will presume the suitability of the nonhuman appropriation of human abolitionist rhetoric and will proceed to critically compare mobilization efforts.

\section{Renascent Abolitionist Factions}

Perhaps the most striking point of comparison for the human antislavery movement and the later nonhuman slavery movement is the evolution of resembling factions. Typical of many social movements (Benford 1993), both the human and nonhuman movements have hosted several factions with varying 
identifications of problems, solutions, motivations, tactics, and goals. Both groups have seen the manifestation of moderate and radical factions that split over the role of religion, the political system, violent advocacy, nonviolent moral suasion, and consumer-based resistance. Factionalism has oftentimes been blamed for draining movement resources and weakening movement identity and mobilization (Benford 1993). Yet, factionalism can be important in addressing shortcomings of mainstream advocacy by invigorating mobilization and ingenuity. In reference to the human abolitionist movement, Bell (1958) explains:

The conflict in ideologies of the period [...] was a source of much disharmony-a disharmony which inhibited action but fostered wide discussion; and the very articulation and evaluation of differences paved the way for more decisive and even militant action in the following years. (39-40)

The nonhuman animal rights movement has extended many of these same tactical debates and has generated similar factions. While religion does not play quite as strong a role as it did with the human movement of the eighteenth and nineteenth century, quite a few advocates do ground their claims-making in religious ideology. Francione's "Abolitionist Approach," for example, is heavily influenced by Jainism, specifically in his emphasis on ahimsa (Francione 2009). Linzey (2009) and Schwartz (2001) have also constructed faith-based rights theory for other animals, and some advocacy groups draw on major religions, notably the Jewish Vegetarians of North America and the Canadian based Christian Animal Rights Effort.

While religion plays a much smaller role in nonhuman abolitionism, the focus on political advocacy solicits much greater attention. Most of the major organizations devote much of their resources to political lobbying and institutional reform. Because these efforts do not call for a radical restructuring of the system, they are indicative of a moderated social movement (Piven and Cloward 1977; Zald and Ash 1966). It is this moderation, and the subsequent dilution of goals, that has encouraged the formation of more radical factions whose discourses are distinctly oppositional to the prevailing system (Beers 2006; Fitzgerald 2000). Large organizations tend to go for the "low hanging fruit," so to speak, in campaigning against practices that are thought unnecessary to industrial operations, such as particularly egregious practices (like workers kicking or beating other animals) (Runkle 2012) or outdated practices. They also tend to support campaigns that are either largely inconsequential to industry production (such as "enriching" cages at relatively little cost to the industry) (HSUS 2011), or actually work to improve it (when reforms are framed as means to reduce worker injury, maximize efficiency, or improve the company's image) (PETA 2007).

As such, the Francionian approach to nonhuman animal rights arose in response to the professionalized movement's hyperfocus on legal advocacy and welfare reforms (Francione 1996). While many professionalized organizations are technically abolitionist in that they seek the complete cessation of nonhuman animal use, their tactical focus on reform suggests otherwise. Francione specifically rejects the moderated approach to activism, finding that it often further entrenches speciesism by increasing economic benefit and public comfort with nonhuman animal use. Instead, he argues that advocates focus on vegan outreach. This outreach, he elaborates, must be nonviolent in nature, as violence is seen as both antithetical to the goal of ending oppression and it exacerbates the public's negative view of advocates. Thus, while abolitionism, in regards to goals, applies to a good number of nonhuman animal rights advocates, Francionian abolitionism, in rejecting any advocacy that complicates or contributes to nonhuman animal use, will guide this discussion. Furthermore, it is Francionian abolitionism that has specifically appropriated the human movement's terminology (specifically in using the term "abolition," but also in equating human slavery with nonhuman slavery and relying on nonviolent, morally based 
tactics). In this he has spearheaded a distinct faction that strongly mirrors the Garrisonian approach to ending oppression.

\section{Tactical Comparisons}

\section{Direct Action}

Nonviolent direct action has been a fundamental tactic to both abolitionist movements. For human abolition, perhaps the most well known form of direct action is embodied by the runaway slave. Slaves enacting their own freedom, methods of assisting runaways including Harriet Tubman's Underground Railroad, and Northern resistance to the American Fugitive Slave Act were important actions that directly challenged human bondage. While these actions were symbolically very important, it remained that structural constraints imposed significant opportunity costs for runaway slaves and those who harbored them. Indeed, most slaves did not attempt their freedom, and for those few that did manage to escape, there was nothing stopping their previous owners from replacing them. The utility of this tactic, therefore, was somewhat limited.

The most relevant comparison of direct actions in nonhuman advocacy comes in the form of open rescues. Advocates have freed nonhumans from laboratories and agricultural facilities under the premise that this immediately helps those nonhumans rescued and that it is symbolically important in raising awareness to the immorality of nonhuman animal use. Francionian abolitionists largely reject the utility of direct action for challenging speciesism (Francione and Garner 2010). As was the case for the human slave system, the institutions remain unchallenged economically or politically. Thus, those rescued nonhumans are simply replaced. Furthermore, these forms of direct action remain illegal in both cases. This is problematic in fueling reactionary policies that both complicate and criminalize movement activities. Alternatively, Francione argues that the promotion of veganism is a pragmatic alternative that does not create opportunity costs for activists. Creating an economic threat to nonhuman animal institutions and the creation of a vegan culture both constitute actions that directly challenge nonhuman slavery.

\section{Slave Resistance}

In both movements, we know that the oppressed have been unhappy with their condition and thus desire to be free based on individual attempts at resistance on their own behalf. In the human movement, this is seen in the many instances of "runaway slaves," Harriet Tubman's Underground Railroad, slave rebellions, and slave narratives. African American resistance validated and invigorated the human abolitionist cause (Ashworth 1995). While nonhumans lack the voice to express their discontent, they express their desire for freedom in countless instances of retaliation and escapes (Hribal 2010). These resistant actions undermine the popular belief that humans and nonhumans flourished in their bondage. This belief, of course, has been a powerful one in recognizing or countering calls for liberation. Selfliberated humans and nonhumans alike become powerful symbols for the abolitionist cause. Escaped slave Frederick Douglass, for example, played an important role in representing African American discontentment and the social injustices of slavery. A prolific activist, lecturer, and author, Douglass became an icon of abolition, challenging racist ideologies and inspiring mobilization (Brown 2004). Emily, a runaway cow, has served a similar role for the nonhuman abolitionist movement. Her heavily publicized escape from a slaughterhouse demonstrated her desire to be free and encouraged the public to see nonhumans as persons. Now immortalized in statue at the Peace Abbey in Massachussets, Emily has become a symbol of nonhuman abolition and anti-speciesism (Randa 2007). Thus, personal resistance has important symbolic power that can challenge oppressive ideologies and privileges and motivate movement participation. 
The species barrier, however, creates a unique challenge for nonhuman abolitionists. This happens in two respects. First, nonhumans are unable to speak on their own behalf, and, second, many nonhumans are the product of several centuries of domestication that has left many of them unaccustomed to freedom and unable to survive without human husbandry. Antebellum African Americans, too, however, were often unable to speak on their own behalf. While print narratives and lectures were hugely influential, they were not accessible venues to most African Americans. Social and political realities meant that African American voices were often censored and ignored. As we've seen, literacy laws in many regions made it illegal for African Americans to access education. Barriers to education meant that African Americans were further limited in both articulating their desire to be free and their recognition of that desire in the first place. Ideological and cultural influences, often the product of many decades or centuries, meant that the majority of African Americans did not see freedom as an option. Social, political, and economic realities outside the plantation also made resistance seem futile. Even today, social, political, and economic barriers continue to disenfranchise many African Americans, thus limiting their abilities and influence. So, while nonhumans physically lack human voice and are biologically altered by domestication, African Americans experience similar socially imposed restrictions on their potential for resistance.

Yet, these species-related differences pose especially difficult challenges to nonhuman mobilization. There is no nonhuman equivalent to Frederick Douglass' influential lecture tour (Buccola 2012). Nonhumans cannot reach out to human society and speak from their own experiences in their own words, and most nonhuman animals who liberate themselves are recaptured or killed (Hribal 2010). Freed blacks and runaways in America could find refuge in Northern states, Canada, or abroad and had the occasional assistance from those who ignored fugitive slave laws. Nonhumans can only rely on even more thinly dispersed network of private individuals and a handful of nonhuman sanctuaries. While sanctuaries are hugely important in giving a face and story to the billions of exploited nonhumans, there are discouragingly few free nonhuman icons and leaders to inspire movement participants and the public.

Because advocates are unable to draw on personal nonhuman narratives and have significantly fewer instances of self-liberation to call attention to, they more often rely on depictions of suffering (DeCoux 2009). This is often achieved through second-person narratives, graphic imagery, and other moral shocks. However, these tactics are more heavily utilized by advocacy organizations whose primary activities are welfare reform. Abolitionist advocates thus tend to downplay moral shocks in favor of rational argument (Wrenn 2013). This generally entails a focus on the property status of nonhumans, as welfare reforms are seen as inconsistent with nonhuman liberation. Indeed, Francione argues that welfare reforms are generally economically beneficial to exploitative industries and tend to increase public comfort with nonhuman animal use (Francione and Garner 2010). Thus, because depictions of suffering are heavily associated with the welfarist approach, it could prove difficult to utilize them in an abolitionist context (Wrenn 2013). Yet, DeCoux (2009) suggests that ignoring suffering interferes with goal attainment: "Abolitionists' lack of success in their efforts to promote veganism may well result from their nearly exclusive focus on the property status of animals as the evil that needs to be overcome" (33). The successful appropriation of welfarist tactics which are traditionally associated with compromising reforms, however, might detract from an abolitionist goal in obscuring the need to end use rather than reform it.

\section{Violence}

As another form of direct action, the use of violence in the human movement had rather mixed results. Though originating as a movement of nonresistance, many abolitionists did come to accommodate violent resistance (Perry 1995). In the United States, slave rebellions (notably Nat Turner's rebellion and John Brown's raid) had the detrimental effect of reassuring many Americans that slaves could not be safely freed. These violent tactics not only strengthened slave laws but also reduced much of the public 
sentiment for antislavery activism (Ferrell 2006). Ashworth (1995) explains: "The attempted insurrection made many southerners feel highly vulnerable and filled them with anger and anxiety at the prospect of a militant attack by northern opponents of slavery" (132). Many blamed abolitionists for inciting violent uprisings, and in reaction to the violence, Southerners became intolerant of criticisms and began to limit rights to free speech. It should be noted, however, that in Britain, the slave uprisings in the island colonies were indeed influential in reinforcing the growing notion that slavery was not a maintainable system. Disturbance and insurgency do have the potential to garner attention and reaction (Piven and Cloward 1977). So, while violence may not have evoked a concern for human rights among Britons, it did fan a growing discomfort with the instability of slavery as the wage system popularized (Drescher 2002).

In the nonhuman movement, however, violence has been largely disastrous. Some activists have resorted to property damage, threats, and other forms of sabotage. These are intended to inflict substantial costs to exploitative institutions or to foster fear in employees and owners in hopes of deterring them from their speciesist practices. Alternatively, many nonhuman animals, acting on their own behalf, have utilized violence against exploiters. In both cases, however, violence is ineffectual in creating meaningful change. Indeed, violence tends to result in swift extinguishment, increased opportunity costs, and more legal restrictions. Notably, violent activism propelled the passage of the Animal Terrorism Enterprise Act (Lovitz 2010; Potter 2011). This act, largely supported by nonhuman animal industry lobbyists, ensures that any activism that interferes with nonhuman use could be deemed criminal. The act's vague wording leaves even peaceful activism vulnerable. For nonhuman animals who utilize violent tactics (though they can hardly be to blame for such actions), the results are even more tragic. Nonhumans who retaliate, show aggression, or otherwise attack their exploiters often suffer increased restraints on their freedom or receive severe punishment. In many cases, they are outright killed (Hribal 2010).

Beyond the political realities that make violent tactics impracticable, violence in the nonhuman animal movement also has the effect of souring public sentiment. Indeed, many advocates for other animals are stereotyped as radical, fanatical, dangerous, and, as the Act would suggest, terroristic. Most nonhumans who retaliate against exploiters receive little sympathy, and are instead framed as beasts and ungrateful brutes who require immediate destruction. Importantly, however, violent tactics are fundamentally antithetical to the nonviolent, egalitarian world that activists wish to achieve. Engaging in violence demonstrates that activists have failed to disentangle themselves from that violent society they so wish to change (Hall 2006). Alternatively, Chenoweth and Stephan (2011) find that nonviolent movements, in their ability to present less risk, attract more participants, and thus mobilize more resources, are, on average, more likely to succeed. What's more, they argue that nonviolent social change is more likely to be lasting. In this sense, the nonhuman movement has repeated some unfortunate mistakes of its predecessor. Violence in the American human movement tended to create public backlash, strengthen legal barriers, and ran counter to abolitionist ideals of peace and community. The nonhuman movement is experiencing similarly unfortunate results.

\section{Moral Suasion}

As an alternative to violent measures, moral suasion was a favored tactic among American abolitionists, though certainly not shared by all. Initiated by the Quakers and free blacks in the North, it was heavily promoted by William Lloyd Garrison (Adeleke 1998). Activists hoped to convince the public that slavery was unjust, not simply economically or politically problematic:

It was an integrative and optimistic ideology, informed by faith in the potency of universal values-values that supposedly impacted humanity equally. It advanced a world view that defined progress as the result of the triumph of universal moral ideals, deemed sufficiently potent, if properly cultivated, to transform 
blacks into accepted and integral members of the human family. It also reflected a strong faith in man, in his reasoning ability, and his inclination for progress. (Adeleke 1998: 128).

Social change, it was thought, would sprout from a shift in public opinion rather than through violence or legislation (Ferrel 2006). In the United States, divisions arose among free blacks who debated as to whether abolitionists should work towards a universal moral improvement on society or if there should be a more race-conscious encouragement of African American self-improvement to combat prejudice (Bell 1958, Quarles 1969).

As previously discussed, religion was central to many abolitionist arguments for morality (Bell 1958), reflecting revivalist and temperance trends of the era (Curry and Goodheart 1982; Midgley 1996). Indeed, some specifically criticized the church in perpetuating racial prejudice. However, many abolitionists, including Garrison, rejected attempts to reform the church, as the church was presumed too deeply entangled in its support or neutrality towards slavery. This tactic also relied heavily on nonviolence (Curry and Goodheart 1982). But support for nonviolence was often contradictory and ambiguous, and by the late 1850 s, violence became increasingly accepted as a means of resistance. Moral suasion was seen to have been a failure and largely unrealistic given the violent climate of antebellum America.

Nonhuman abolitionists, too, have put considerable weight in the notion that humanity is fundamentally interested in progress and that reason is the most appropriate tool for mobilizing social change. Historical nonhuman mobilization drew on human abolitionist efforts in their reliance on moral suasion, establishing humane education departments that sponsored newsletters and pamphlets, youth clubs, and lectures in schools and churches (Beers 2006). Today, Francionian abolitionism in particular relies heavily on moral suasion that rooted in rationality. Yet, overreliance on this tactic, as we have seen, has been questioned by those contending that emotional appeals and depictions of suffering are equally important (DeCoux 2009). Alternatively, other abolitionists have criticized Francionian abolitionism for not being rational enough (Johnson 2012). For instance, Francione (2012) rejects the fundamental necessity of rational discourse in outreach efforts, allowing for advocacy based in spirituality, compassion, and other subjectivities. Still others, as previously discussed, hold a pessimistic view in regards to the moral capabilities of the public and instead rely on legislative, direct, or violent actions to compensate.

\section{Consumer-Based Resistance}

Another nonviolent tactic of the abolitionist movement surfaced briefly to take advantage of the economic connections between activists, the public, and the enslaved. In the late 1700 s and early 1800 s, British boycotts on slave-produced products, namely sugar and rum, became a popular form of resistance that was accessible to anyone. Abolitionists distributed thousands of leaflets encouraging the public to forgo the items. It was thought that these economic pressures might expedite the abolition of slavery and the campaign was one of the first to frame injustice in terms of consumer responsibility (Glickman 2004).Grocers recognized the ethical concerns of their customers and began offering less objectionable alternatives, as evidenced in a Suffolk merchant's advertisement:

Therefore being impressed (as I have said) with the Sufferings and Wrongs of that deeply-injured People, and also with an Apprehension, that while I am a Dealer in that Article which appears to be a principal Support of the Slave Trade, I am encouraging Slavery, I take this Method of informing my Customers, that I mean to discontinue selling the Article of SUGAR (when I have disposed of the stock of I have on Hand) till I can procure it through Channels less contaminated, more unconnected with Slavery, and less polluted with Human Blood. (Wright 1792). 
Purchasing fairly traded products and boycotting particular items is argued to be an important political statement and powerful economic resistance (Dickinson and Hollander 1991; Micheletti and Follesdal 2007; Pivin 2008). Consumers are able to repurpose exploitative economic systems as a means for alleviating inequality and oppression (Evans 1989; Parker 1999). Abstention from slave-produced commodities also reflected the movement's focus on moral reform and created a notion of personal responsibility in the public (Midgley 1996). Sales of slave-harvested sugar dropped by over a third, while sugar produced by free labor in India increased substantially. However, much of the public found the sacrifice difficult to justify as sugar was a popular and highly-valued commodity heavily integrated into British culture by that time (The Economist 2006; Midgley 1996). This is evidenced in a poem from the period:

I pity them greatly, but I must be mum,

For how could we do without sugar and rum?

Especially sugar, so needful we see

What give up our desserts, our coffee, and tea? (Cowper 1788)

Indeed, the popularity of the boycott declined in Britain after the abolition of the slave trade in 1807. However, following British example, the practice took hold in the United States in the 1820s and some grocers began offering fair trade produce (Glickman 2004). American attempts at consumer-based resistance were limited as well and the campaign never reached the higher levels of mobilization that the British counterpart had enjoyed. Fair trade products were generally restricted to the North and by the 1840s abolitionists began to abandon the tactic as futile. It was thought that asking the public to forgo certain products would frame the abolitionist movement as overly virtuous and puritanical. The availability and affordability of slave-produced products also hampered success (Midgley 1996). And, in both nations, the genuineness of free produce was often in question (Glickman 2004).

The nonhuman abolitionist movement has taken a similar route in the promotion of veganism. There is an important distinction between commodity boycotts in the human and nonhuman movements, however. While sugar was an integral commodity in British life, sugar produced by free labor in India was an available alternative, and overall, British citizens were not required substantial changes in their consumptive practices. But, in addition to the call for boycotts against consumptive practices that indirectly harm nonhumans ("dairy," eggs, attending horse races and rodeos, and purchasing products tested on nonhumans, for example), abolitionists for the nonhuman animal cause also call for boycotts against products and activities that directly harm nonhuman animals. This would include consumption of flesh and skins, breeding domesticates, and hunting. As such, the nonhuman movement requires a boycott that asks consumers to change a great number of personal behaviors. Analogs to nonhuman animal products might operate as the fair-trade sugar option for antislavery advocates, and many organizations do actively promote these. But while vegan alternatives are increasingly available, specialty items and vegan restaurants tend to be concentrated in urban centers and higher income areas.

Boycotts for other animals are more focused on direct exploitation than their human counterparts. The British movement asked individuals to reject slavery, but the majority of the public did not directly participate in slaver ownership (though many indirectly benefited from a slave-based society). Therefore, human abolitionists necessarily reached beyond directly harmful practices to include the byproducts of slavery that indirectly supported the system. This approach provided them a much larger constituency, but this was facilitated by the fact that most participants might be more easily persuaded to join the cause as they were not directly involved in exploitation.

The nonhuman movement, however, faces the difficult task of challenging the public's direct participation in exploitation-most Britons and Americans regularly consume large amounts of nonhuman animal 
products. True, the slave owners in this modern example (farmers, vivisectors, etc.) are those who most directly benefit from commodifying nonhuman animals for profit in a speciesist society, but the consumers' direct contact with the bodies and labor of nonhuman animals is a relatively unique challenge. As such, abolitionists have had difficulty balancing their need to identify the adversary without simultaneously alienating potential new adherents (Maurer 2002). In addition to this, still other advocates charge that veganism does not go far enough. Harper (2010) encourages vegans to reexamine the ethical shortcomings of many vegan and "cruelty-free" foods such as tomatoes, sugar, and soda. And, the campaign against palm oil takes issue with unsustainable production practices that are hugely destructive for rain forest ecosystems and particularly disastrous for orangutans (Bartolotta 2012). Though, reflecting abolitionist criticisms of the free produce campaign of yesteryear, vegans are in debate as to the usefulness of boycotts of products with such indirect connection (Nashville-Veg 2012).

Furthermore, the mainstream nonhuman movement has stigmatized vegan outreach for fear of appearing too radical, puritanical, and elitist (Francione and Garner 2010). Professionalized organizations tend to shy away from veganism for fear of undermining the movement's accessibility and popularity (Friedrich 2010; Joy 2008; Norris 2009). Indeed, many advocates adopt a pessimistic view quite reminiscent of human rights abolitionists of the 1800 s and reject the potential in promoting veganism. But unlike the human abolitionist movement that largely abandoned appeals to the consumer, the nonhuman abolitionist movement continues to hold veganism as the moral baseline (Francione and Garner 2010). Consumerbased resistance is arguably the linchpin of nonhuman abolition advocacy. According to Francionian abolitionism, one cannot be considered abolitionist if one is not vegan. Again, veganism is distinct from the free produce campaigns utilized by human rights abolitionists in that it includes the rejection of direct consumption of nonhumans, so this requirement is certainly more reasonable. One could not be considered a human rights abolitionist and own slaves, for example, so nor could one be considered an abolitionist for other animals and eat or wear their flesh. This ethical consistency is more fundamental to nonhuman abolitionist mobilization than it was for human efforts. This is perhaps one area where the movement for other animals could succeed where the human abolitionist efforts failed. While the human movement abandoned consumer-based resistance relatively quickly, and arguably never put much faith in the tactic to begin with, abolitionists for other animals hold veganism as an indisputable requirement for abolitionist advocacy-activists are expected to be vegan and to base their advocacy in promoting veganism. Although short-lived for antebellum abolitionists, the free produce campaign generated the more important and longer-lasting success in helping to create an antislavery culture. So, while veganism might have initial difficulties in posing a significant economic threat to nonhuman industries, its role in normalizing anti-speciesism could prove invaluable.

\section{Legislative Efforts}

Support for moral suasion and consumer-based resistance was certainly far from universal in the human abolitionist movement. These tactics represented a lack of faith in the government to enact change (Midgley 1996), but many abolitionists still looked to the government to for real influence, regularly petitioning congress (Ashworth 1995), forming parties in the 1840s and 1850s, and working to undermine Southern political power in Congress (Ferrell 2006). Political efforts were often thwarted, however, as evidenced in the Gag Rule of the 1830 s and 40 s, which automatically tabled slave-related petitions. This only served to fuel petition drives, and collecting signatures became a popular form of advocacy both in the United States and in Britain. Early abolitionist political campaigns favored gradual emancipation or the emigration of blacks to colonies in Africa. Free blacks, and eventually Garrison, however, rejected these compromising propositions in favor of immediate abolition (Ferrell 2006). By the 1830s, Garrison and other American immediatists would come to dismiss political action and preexisting legal apparatuses altogether as a hopeless endeavor (Ashworth 1995). Others, Douglass included, saw that governmental 
intervention was a necessary counterpart to moral suasion, as appeals to reason appeared increasingly futile (Curry and Goodheart 1982). It cannot be denied that legislative acts were hugely important for the human abolitionist movement. Britain's 1807 Slave Trade Act and 1833 Slavery Abolition Act (provoked by a barrage of antislavery petitions) and a litany of state prohibitions in the Northern United States, and, in the 1860s, the emancipation proclamation, thirteenth, and fourteenth amendments were all critical victories for the abolitionist cause. They created social change on a scale unmatched by other tactics. However, without a significant challenge to the ideologies that supported slavery, smuggling persisted after the abolition of the slave trade and slavery certainly persisted in other forms such as debt peonage and sharecropping following the abolition of slavery (Ferrell 2006).

Today, the nonhuman animal movement tends to rely very heavily on legislative efforts. Much of this draws on the pessimistic assumption that a good majority of the public will remain immune to calls for morality and reason. In particular, Robert Garner has been skeptical of the utility of vegan outreach, arguing that it will be impossible to enforce moral choice without political and legal support. Indeed, many mainstream nonhuman organizations supplement their social reform efforts with legislative campaigns aimed at reforming use or banning particular practices. While much of this work is carried out by organizations, the public is mobilized in petition signing and through the vote. California's Proposition 2, for example, sought to improve living conditions for nonhumans used for human consumption. Passed in 2008, the initiative was led by the HSUS, the ASPCA, and other major animal organizations, entailing a great deal of campaigning and petition signing. However, in that the proposition would only create minor (arguably insignificant) improvements that were not required for some years, Francionian abolitionists mark this proposition (and others like it) as a failure. Indeed, according to Francione (1996), legislative "victories" such as these tend to reflect agricultural practices that are inefficient and likely to be eradicated regardless of any legislation. For example, in an economic report prepared by PETA that campaigned for the controlled atmosphere killing of chickens, the switch is touted as profitable to producers in increasing production capacity, improving working conditions, reducing carcass damage and labor costs, and improving food quality (PETA 2007). More recently, Mercy for Animals persuaded Kraft suppliers to do away with the "unnecessary" practice of tail docking in dairy cattle. As they explain, it, "[...] serves no benefit for animals or dairy workers [...]" (Mercy For Animals 2012), and it is "purposeless" and "outdated" (Runkle 2012). The exploitation and killing of nonhumans is effectively streamlined, the commodification of nonhumans remains unaddressed, and only those practices that can be framed as economically beneficial to eliminate (or at least framed as "unnecessary" to production) tend to be addressed.

Francione (2010) also warns that legislative efforts create the illusion that injustices have been acknowledged and remedied, thus creating a public comfort with continued use and exploitation of nonhumans. Indeed, the notion of higher welfare, touted by industry and animal groups alike, has supported the growth of the now booming "humane" nonhuman animal product industry. No serious challenge to nonhuman animal consumption is offered. Instead, that consumption continues on vigorously and largely unabated. And it is able to do so under the illusion that nonhuman animals are exploited and killed "compassionately," an illusion propagated by welfare organizations that purport to represent the interests of other animals.

Thus, it has been the case that reliance on legislation inevitably only succeeds in heavily diluted social change and regulation instead of eradication. Because nonhuman animals remain property, this is an understandable outcome. Antislavery advocates had the benefit of at least some social recognition of African American personhood, and this was supported in the sizable population of free blacks. But if nonhuman animals property status goes unchallenged, any legal mobilization on their behalf could only reasonably hope to modify their enslavement. This tactic has therefore been at the root of significant 
factionalism in the nonhuman movement beginning in the nineteenth century (Beers 2006). A rejection of legislative actions altogether seems to characterize Francionian abolitionism as it did for Garrisonian abolitionism. Legislative efforts might be favored because they are low-risk and low-cost forms of advocacy in that they attempt social change through preexisting sanctioned venues. Francione counters, however, that legislation will be ineffectual and sorely limited without a public support for abolition. He also postulates that, once a critical mass of vegans has been achieved, legislations would be stronger and could encompass those resistant to anti-speciesism.

\section{Media}

In addition to legislative efforts, the human rights abolitionist movement relied heavily on the distribution of literature to promote liberation. This was especially necessary for an unreceptive Southern population: "The post office offered an excellent agency to convey their propaganda to parts of the country where they could not appear in person" (Savage 1928: 156). But, this outreach met significant resistance. Southern states offered bounties for some editors and authors of abolitionist literature which was considered seditious, morally degrading, and apt to incite restlessness among slaves. Many Southern states went so far to ban abolitionist literature entirely. Penalties for breaking these laws included large fines, punishment, and even death. Savage (1928) notes, however, that these bans did not deter Northern abolitionists from distributing their literature to the South. Though, oftentimes, Southerners detained and destroyed the materials from post offices. Post offices sometimes complied with Southern objections, while other times they sided with the abolitionists' constitutional rights to distribution. This tension eventually culminated in government intervention, which ultimately favored the postmaster's constitutional duty to distribute even those mails that might be considered objectionable-though this law was not fully obeyed.

Popular literature, of course, was also hugely influential for the abolitionist cause. Novels like Harriet Beecher Stowe's Uncle Tom's Cabin (and two decades after the abolishment of slavery, Mark Twain's Huckleberry Finn) and slave narratives like Frederick Douglass's autobiography challenged romanticized views of slavery, humanized victims, roused sentiment, and motivated abolitionist collective action. These works were hugely influential in combating countermovement mobilization and prevailing racist ideologies. The advent of photography was also an important resource for abolitionists. Photographs of slaves, though rare, were mass produced and widely distributed (Berger 2011). These images graphically depicted the impact of slavery and gave a face to victims.

Similarly, activists for other animals have relied heavily on the media and have been quick to take advantage of technological innovations. Sewell's 1877 Black Beauty and Singer's 1975 Animal Liberation were both hugely influential in creating public awareness of nonhuman suffering (Beers 2006). And, Francione's 1996 Rain without Thunder was efficacious in mobilizing the abolitionist movement for other animals. Yet, the movement for other animals also faces significant censorship and bias that has been markedly detrimental to the cause. Messages of nonhuman liberation are generally excluded from mass media (Blaxter 1999) if not generally misrepresented in a speciesist environment (Kew 2003). Vegans and other nonhuman rights activists that do reach media platforms overwhelmingly experience negative portrayals and stereotyping (Cole and Morgan 2011). Instead, the media tends to reinforce the speciesist status quo in supporting the commodification of other animals (Freeman 2009). The abolitionist message is further obscured by professionalized nonhuman animal organizations which frame the discourse as one of welfare reform, effectively ignoring and downplaying the importance of veganism and abolitionist work (Francione and Garner 2010). The result is a doubly reinforced barrier whereby the abolitionist movement must combat industry countermovement and inner-movement censorship. 
Fortunately, the nonhuman movement has been able to utilize modern technologies, primarily the internet, to challenge and partially overcome these obstacles. Indeed, the internet might stand as the most critical difference between human and nonhuman abolitionist mobilization. Online collective action imposes far fewer opportunity costs: It is widely available, relatively affordable, moves information quickly, poses fewer personal risks to activists, and can reach a large, global audience (Earl and Schussman 2003). For marginalized abolitionists struggling to find voice in the professionalized nonhuman animal rights movement, the internet provides low startup costs, fosters entrepreneurialism, and gives platform to abolitionist messages that are otherwise ignored. Advocates for other animals also have the advantage of film and television, and many videos have been widely distributed that graphically depict the true conditions of nonhuman animal exploitation. So, while the nonhuman movement also relies heavily on secondary narratives and literature, it might draw a unique strength in its access to internet mobilization, film, and television.

\section{Transnational Mobilization}

A final tactic worth mentioning that was utilized by the human rights abolitionist movement and is reflected in nonhuman animal rights mobilization today is the reliance on transnational mobilization. Although some degree of tactical diffusion was responsible for the American efforts, British activists did actively assist and encourage Yankee abolitionists. This was particularly helpful after Britain had successfully outlawed slavery themselves (Ferrell 2006). American activists networked heavily with British advocates and drew heavily on their tactics. Certainly, transnational mobilization is not unique to the human abolitionist movement, and is characteristic of many new social movements today, but it does hold particular relevance to the movement for other animals. Nonhuman abolitionists, Francionian abolitionists in particular, are geographically disperse. Transnational networking is an important means for activists across the globe to coalesce, pool resources, and strategize. Again, the internet in particular has played a key role in facilitating this mobilization (Francione and Garner 2010).

Research into transnational coalitions for human rights has suggested that development can be stunted where such coalitions are absent, lending weight to the importance of transnational efforts for movement growth (Chilton 1995). But transnational mobilization is not without its shortcomings, however. For instance, the spread of economic liberalization and the idealized Western notion of rights associated with this trend are not universally accepted and this might limit the reach of claims making on behalf of other animals. If the imposition of Western human rights has met resistance and disagreement, certainly Western ideas of rights for other animals will face even greater difficulty in obtaining global recognition. This may also be reason for the current Western focus of the movement, with mobilization primarily constrained to the United States, Canada, the United Kingdom, Western Europe, Australia, and New Zealand. Transnational rights efforts must also contend with political opportunities that fluctuate regionally (Smith 1995), and cooperation can sometimes exacerbate existing movement barriers by complicating organization and introducing cultural and ideological conflict (Maney 2000; Princen 1995). Thus, emerging movements for other animals in nonwestern nations could face significant tensions as the realities of domestic structures clash with Western transnational efforts (Jacobsson 2013).

\section{Goal Attainment}

In the American human abolitionist movement, the goal of ending slavery was achieved by the midnineteenth century. However, the human movement, largely rooted in economic considerations, failed to take into account racist ideologies that continue to persist long after abolition. Indeed, the egalitarian promise of the Reconstructive Era was quickly compromised as policies, procedures, and institutions settled back into discriminatory practices. African Americans were excluded from voting, intermarriage was outlawed, sharecropping replaced slavery, and segregation prevailed. DuBois spent much of his 
career combating these social problems in arguing for desegregation, educational opportunity, and political representation for African Americans (Lewis 1995). It was not until the Civil Rights Movement, arguably the second wave of the American abolitionist movement, that we began to see significant challenges to racist ideology and the meaningful realization of egalitarianism. This is not to say that racism has been completely eradicated. Certainly, many social institutions remain terribly discriminatory, as Davis (2005) explores in her criticism of the modern prison-industrial complex and Massey and Denton (1993) in their exploration into segregated housing, for example. Regardless, it should be clear that a movement to end the property status of sentient persons must also consider strong ideological impediments that can quickly undermine abolitionist victories.

Despite its shortcomings, the human movement has quite obviously surpassed the movement for other animals. As of this writing, nonhuman animals legally remain property and are exploited and killed by the billions each year. According to Francione (1996), the modern nonhuman movement, practicably in existence for over 200 years, has failed to realize any significant improvement for the status of nonhumans. Pointing to increasing welfare legislation, some have suggested that violence towards nonhuman animals has been decreasing (Pinker 2011). However, processes of globalization have led to dramatic increases in nonhuman animal exploitation (Wrenn 2011). This exploitation is likely to see continued growth so long as Western dietary norms are idealized and nonhuman animal products are associated with wealth and prosperity. As Donaldson and Kymlicka (2011) explain: "The animal advocacy movement has nibbled at the edges of this system of animal exploitation, but the system itself endures, and indeed expands and deepens all the time, with remarkably little public discussion." Thus, violence towards nonhuman animals continues relatively unabated. An industry of "higher welfare" products has blossomed in wealthy nations where there is considerable profit to be made from assuaging consumer guilt with nonhuman animal exploitation. As Francione demonstrates, "humane" laws tend to be arbitrary, inconsistent, poorly enforced, and minimally influential. In failing to combine attempts to abolish property status with attacks to ideological impediments, the nonhuman animal rights movement is challenged in much the same way as the human abolitionist movement. The diminished role of anti-speciesist, vegan outreach in favor of reform (Francione and Garner 2010) is indicative of this.

It appears, then, that the movement for other animals is likely to fall into the same pitfall of the human movement that preceded it. Without attacking speciesism, no amount of bans and reforms are likely to seriously challenge the oppression that other animals face. Property status and oppressive ideology must be tackled in tandem as they are mutually reinforcing. Furthermore, unlike the human movement that witnessed economic tensions that challenged the perpetuation of the slave system, nonhumans continue to function as integral commodities in modern agricultural, entertainment, and scientific institutions. It is not likely that external economic weaknesses will challenge nonhuman animal exploitation in the near future. This is especially troubling as many professionalized nonhuman animal advocacy groups, as we have seen, successfully implement reforms in promoting them as economically beneficial to industry (Francione 1996). Because such groups actually cooperate with exploiters, they cannot reasonably be expected to challenge the property status of other animals or an ideology of speciesism. We might speculate, however, that the impending global environmental crisis, severely aggravated by nonhuman animal agriculture, might expedite abolitionist efforts. Again, however, without a challenge to speciesism, it is unlikely that nonhumans will receive any substantial improvement in their status.

\section{Conclusion}

With this brief exploration into the tactics historically favored by human rights abolitionists, we see the resurgence of many of the same techniques, ideological differences, and subsequent divisions in nonhuman animal rights activism. Liberation efforts on behalf of humans were met with some success; while "open rescues" for nonhuman animals have been decidedly less useful. Narratives, a favorite tactic 
of human abolitionists, have not transferred as neatly to nonhuman animal activism and must be interpreted and represented by humans. Violence met with mixed success for human antislavery efforts, but has been an arguable failure for nonhuman animal antislavery efforts. Moral suasion, characteristic of early abolitionist efforts (and later deemphasized or abandoned altogether), has been enthusiastically recovered by Francione and other abolitionists and held as the baseline for effective advocacy. Boycotts, too, which enjoyed only fleeting popularity in antebellum America, have become essential to nonhuman animal abolitionist efforts. It has been suggested that a serious vegan campaign might succeed where consumer-based resistance has failed for human abolitionists. Legislative mobilization, on the other hand, while critical in achieving human rights and a popular tactic for nonhuman animal welfare organizations seeking reform, has been largely absent from abolitionist work on behalf of other animals. Francione is clear on his position that legal mobilization will fail to enact any meaningful change so long as the property status of other animals remains unchallenged and there is no attack on the ideology of speciesism. Antislavery advocates might have enjoyed greater success with such an approach because many free African Americans were already considered legal persons thus exemplifying some degree of social awareness regarding black personhood. Nonhuman animals, on the other hand, universally remain property. However, the media and transnational mobilization might be additional sources of repertoire. Despite anti-literacy laws and Southern interference with abolitionist mailings, human abolitionists were able to utilize photography and literature to mobilize a constituency. Advocates for other animals experience similar censorship barriers, but might use video and internet access to circumvent them. Transnational linkages reinforced these successes in providing American antislavery activists with critical support. Abolitionists for other animals, too, might facilitate transnational coalition building, especially through the use of the internet-a tremendous resource for a diverse, widespread, and marginalized movement faction.

The rift between antislavery advocates of moral suasion, violence, and legislative activism exhibit a striking resemblance to the movement to end nonhuman animal slavery today. Certainly, African Americans and nonhuman animals have unique experiences that limit comparison, but the movements that represent them against discrimination and enslavement operate quite similarly and embody ongoing debates in goal attainment. Perhaps the human antislavery movement can speak to the utility of particular tactics and ideologies for other antislavery efforts. Alternatively, the movement for other animals might pave the way for demonstrating the success in other tactics and mobilization ideologies, particularly an adherence to nonviolence and consumer-based resistance.

\section{Acknowledgments}

I extend my gratitude to Randy Sandberg and Matthew Roberts for their support, encouragement, and contributions in the conception and construction of this manuscript and also the anonymous reviewers of an earlier version of this paper for their helpful comments.

\section{References}

Adeleke, T. (1998). Afro-Americans and moral suasion: The debate in the 1830's. The Journal of Negro History, 83(2), 127-142.

Ashworth, J. (1995). Slavery, capitalism, and politics in the antebellum republic. Volume 1: Commerce and compromise, 1820-1850. Cambridge: Cambridge University Press.

Bartolotta, K. (2012). If it contains palm oil, is it vegan? Elephant Journal. http://www.elephantjournal. com/2012/03/if-it-contains-palm-oil-is-it-still-vegan-kate-bartolotta-waylon-lewis/. Accessed 16 Apr 2012. 
Beers, D. (2006). For the prevention of cruelty: The history and legacy of animal rights activism in the United States. Athens: Ohio University Press.

Bell, H. (1958). The American moral reform society, 1836-1841. Journal of Negro Education, 27(1), 3440.

Bendford, R., \& Snow, D. (2000). Framing processes and social movements: An overview and assessment. Annual Review of Sociology, 26, 611-639.

Benford, R. (1993). Frame disputes within the nuclear disarmament movement. Social Forces, 71(3), 667-701.

Berger, M. (2011). Seeing through raced: A reinterpretation of civil rights photography. Berkeley: University of California Press.

Blaxter, J. (2009). As seen on TV—or seen off? Towards a vegan media critique. Critical Society Winter, 1, 7-14.

Boyd, B. R. 1987. The new abolitionists: Animal rights and human liberation. Taterhill Press.

Brown, N. (2004). 'Send back the money!' Frederick Douglass's antislavery speeches in Scotland and the emergence of African American internationalism. Scotland's Transatlantic Relations Project Archive. http://www.iash.ed.ac.uk/star/archive/Papers/Brown_Douglass.in.Scotland.pdf. Accessed 19 April 2012.

Brown, E. (2012). SeaWorld of pain.The Daily Show. Episode \#17058, February 15. Comedy Central. http://www.thedailyshow.com/watch/wed-February-15-2012/seaworld-of-pain. Accessed 16 Mar 2012.

Buccola, N. (2012). The political thought of Frederick Douglass: In pursuit of American liberty. New York: New York University Press.

Campbell, J. (2007). Slavery on trial: Race, class, and criminal justice in antebellum Richmond, Virginia. Gainesville: University Press of Florida.

Chenoweth, E., \& Stephan, M. J. (2011). Why civil resistance works: The strategic logic of nonviolent conflict. New York: Columbia University Press.

Chilton, P. (1995). Mechanics of change: Social movements, transnational coalitions, and the transformation processes in Eastern Europe. In T. Risse-Kappen (Ed.), Bringing transnational relations back in: Non-state actors, domestic structures, international institutions (pp. 189-226). Cambridge UK: Cambridge University Press.

Cole, M., \& Morgan, K. (2011). Veganphobia: Derogatory discourses of veganism and the reproduction of speciesism in UK national newspapers. The British Journal of Sociology, 62(1), 134-153.

Cornelius, J. (1991). 'When I can read my title clear' literacy, slavery, and religion in the antebellum south. Columbia, SC: University of South Carolina Press.

Cowper, W. (1788). Pity for poor Africans. Society for the Abolition of the Slave Trade.

Curry, R., \& Goodheart, L. (1982). Ambivalence, ambiguity, and contradiction: Garrisonianabolitionists and nonviolence. The Journal of Libertarian Studies, 6(3-4), 217-226. 
Davis, A. (2005a). Abolition democracy: Beyond empire, prisons, and torture. New York: Seven Stories Press.

Davis, K. (2005b). The Holocaust and the henmaid's tale: A case for comparing atrocities. New York: Lantern Books.

DeCoux, E. (2009). Speaking for the modern Prometheus: The significance of animal suffering to the abolitionist movement. Animal Law, 16(1), 9-64.

Dickinson, R., \& Hollander, S. C. (1991). Consumer votes. Journal of Business Research, 22(4), 335346.

Donaldson, S., \& Kymlicka, W. (2011). Zoopolis: A political theory of animal rights. Oxford: Oxford University Press.

Drescher, S. (2002). The mighty experiment: Free labor versus slavery in British emancipation. New York: Oxford University Press.

Earl, J., \& Schussman, A. (2003). The new site of activism: On-line organizations, movement entrepreneurs, and the changing location of social movement decision making. Research in Social Movements, Conflicts and Change, 24, 155-187.

Evans, P. (1989). Predatory, developmental, and other apparatuses: A comparative political economy perspective on the third world state. Sociological Forum, 4(4), 561-587.

Ferrell, C. (2006). The abolitionist movement. Westport: Greenwood.

Fitzgerald, K. J. (2000). Radical social movement organizations: A theoretical model. Sociological Quarterly, 41(4), 573-592.

Francione, G. (1996). Rain without thunder: The ideology of the animal rights movement. Philadelphia: Temple University Press.

Francione, G. (2009). Some thoughts on the Abolitionist Approach. The Abolitionist Approach. http://www.abolitionistapproach.com/some-thoughts-on-the-abolitionist-approach. Accessed 16 Apr 2012.

Francione, G. (2012). Moral concern, moral impulse, and logical argument in animal rights advocacy. The Abolitionist Approach. http://www.abolitionistapproach.com/moral-concern-moral-impulse-andlogicalargument-in-animal-rights-advocacyl. Accessed 5 Oct 2012.

Francione, G., \& Garner, R. (2010). The animal rights debate: Abolition or regulation?. New York: Columbia University Press.

Freeman, C. P. (2009). This little piggy went to press: The American news media's construction of animals in agriculture. The Communication Review, 12, 78-103.

Friedrich, B. (2010). Personal purity vs. effective advocacy.Go Veg. http://www.abolitionistapproach.com/media/links/p3136/claims.pdf. Accessed 24 Feb 2012.

Glickman, L. (2004). 'Buy for the sake of the slave': Abolitionism and the origins of American consumer activism. American Quarterly, 56(4), 889-912. 
Hall, L. 2006. Capers in the churchyard: Animal rights advocacy in the age of terror. Darien, CT: Nectar Bat Press.

Harper, A. B. (2010). Race as a "feeble matter" in veganism: Interrogating whiteness, geopolitical privilege, and consumption philosophy of "cruelty-free" products. Journal for Critical Animal Studies, 8(3), 5-27.

Hribal, J. (2010). Fear of the animal planet: The hidden history of animal resistance. Petrolia: AK.

HSUS. (2011). HSUS, egg industry agree to promote federal standards for hens. Retrieved from http://www.humanesociety.org/news/press_releases/2011/07/egg_agreement.html.

Jacobsson, K. (2013). Channeling and enrollment: The institutional shaping of animal rights activism in Poland. In K. Jacobsson \& S. Saxonberg (Eds.), Beyond NGO-ization? The development of social movements in Central, Eastern Europe (pp. 1-35). Farnham: Ashgate.

Johnson, R. (2012). The biggest development in animal rights for a decade. Practical Animal Ethics. http://animalrightsuk.blogspot.com/2012/07/biggest-development-in-animal-rights.html. Accessed 12 July 2012.

Joy, M. (2008). Strategic action for animals: A handbook on strategic movement building, organizing, and activism for animal liberation. Brooklyn: Lantern Books.

Kew, B. (2003). Appropriating liberation. Society \& Animals, 4(1), 29-49.

Kim, C. J. (2011). Moral extensionism or racist exploitation? The use of holocaust and slavery analogies in the animal liberation movement. New Political Science, 33(3), 311-333.

Lewis, D. L. (1995). W.E.B DuBois: A reader. New york: Henry Holt.

Linzey, A. (2009). Why animal suffering matters: Philosophy, theology, and practical ethics. New York: Oxford University Press.

Lovitz, D. (2010). Muzzling a movement: The effects of anti-terrorism law, money, and politics on animal activism. Brooklyn: Lantern Books.

Maney, G. (2000). Transnational mobilization and civil rights in Northern Ireland. Social Problems, 47(2), 153-179.

Massey, D., \& Denton, N. (1993). American apartheid: Segregation and the making of the underclass. Cambridge: Harvard University Press.

Maurer, D. (2002). Vegetarianism: movement or moment?. Philadelphia: Temple University Press.

McAdam, D., Tarrow, S., \& Tilly, C. (2001). Dynamics of contention. New York: Cambridge University Press.

Mercy For Animals. (2012). Your voice is needed to ban cruel tail docking. http://www.mercyforanimals.org/ban_tail_docking_NY.aspx. Accessed 15 Oct 2012.

Micheletti, M., \& Follesdal, A. (2007). Shopping for human rights. An introduction to the special issue. Journal of Consumer Policy, 30, 167-175. 
Midgley, C. (1996). Slave sugar boycotts, female activism and the domestic base of British antislaveryculture. Slavery \& Abolition, 17(3), 137-162.

Moss, H. (2009). Schooling citizens: The struggle for African American education in antebellum America. Chicago: The University of Chicago Press.

NashvilleVeg. (2012). Vegan: One definition. Many perspectives. One big picture. Nashville Veg, April 12. http://www.nashvilleveg.com/vegan-one-definition/. Accessed 20 Apr 2012.

Nibert, D. (2002). Animal rights/Human rights: Entanglements of oppression and liberation. Oxford: Rowman\& Littlefield.

Norris, J. (2009). Does veganism spread itself? Vegan Outreach[Presentation]. http://whyveganoutreach.blogspot.com/2011/12/Friday-video-jack-from-2009.html. Accessed 26 Feb 2012.

Parker, G. (1999). The role of consumer-citizen in environmental protest in the 1990s. Space and Polity, 3(1), 67-83.

People for the Ethical Treatment of Animals. (2007). Controlled-atmosphere killing vs. electric immobilization: A comparative analysis of poultry-slaughter systems from animal welfare, worker safety, and economic perspectives. http://www.peta.org/CAK/CAK?report.pdf. Accessed 5 Oct 2012.

Perry, L. (1995). Radical abolitionism: Anarchy and the government of God in antislavery thought. Knoxville: The University of Tennessee Press.

Pinker, S. (2011). The better angels of our nature. New York: Viking.

Piven, F., \& Cloward, R. (1977). Poor people's movements: Why they succeed, how they fail. New York: Pantheon Books.

Pivin, F. (2008). Can power from below change the world? American Sociological Review, 17, 1-14.

Potter, W. (2011). Green is the new red: An insider's account of a social movement under siege. San Francisco: City Lights.

Princen, T. (1995). Ivory, conservation, and environmental transnational coalitions. Pp. 227-256 in Bringing transnational relations back in: Non-state actors, domestic structures and international institutions, edited by T. Risse-Kappen. Cambridge UK: Cambridge University Press.

Quarles, B. (1969). Black abolitionists. New York: Da Capo.

Randa, L. (2007). The story of Emily the cow: Bovine bodhisattva. Bloomington: AuthorHouse.

Runkle, N. (2012). Kraft foods bans cruel tail docking following MFA investigation at Idaho's largest dairy factory farm. The MFA Blog. http://www.mfablog.org/2012/10/kraft-foods-bans-cruel-tail-dockingfollowingmfa-investigation-at-idahos-largest-dairy-factory-farm.html. Accessed 15 Oct 2012.

Salt, H. (1980). Animals' rights: Considered in relation to social progress. Clarks Summit: Society for Animal Rights.

Savage, W. S. (1928). Abolitionist literature in the mails. 1835-1836. The Journal of Negro History, 13(2), 150-184. 
Schwartz, R. (2001). Judaism and vegetarianism. New York: Lantern Books.

Smith, J. (1995). Transnational political processes and the human rights movement. Research in social movements, conflicts and change, 18, 185-219.

Spiegel, M. (1996). The dreaded comparison: Human and animal slavery. London: Heretic Books. The Economist. (2006). Sick with excess of sweetness. The Economist, December 19. http://www.economist.com/node/8345592. Accessed 16 Apr 2012.

Williams, Eric. (1994). Capitalism and slavery. Chapel Hill, NC: The University of North Carolina Press.

Wrenn, C. (2011). Resisting the globalization of speciesism: Vegan abolitionism as a site for consumerbased social change. Journal for Critical Animal Studies, 9(3), 9-27.

Wrenn, C. (2013). Resonance of moral shocks in abolitionist animal rights advocacy: Overcoming contextual constraints. Society \& Animals, 21(4), 379-394.

Wright, J. (1792). No title. General Evening Post, March 6. http://gallery.nen.gov.uk/gallery1318abolition.html. Accessed 16 Apr 2012.

Zald, M., \& Ash, R. (1966). Social movement organizations: Growth, decay and change. Social Forces, 44(3), 327-341. 